\title{
Comparison of heavy metal concentration of some marine fishes from Black and Aegean Seas
}

\author{
Lubomir MAKEDONSKI, Katya PEYCHEVA* and Mona STANCHEVA \\ Department of Chemistry, Faculty of Pharmacy, Medical University of Varna, \\ 55 Marin Drinov Str., 9000 Varna
}

\begin{abstract}
Major part of healthy human diet consist of marine fish and seafood products. And it is not surprising that there are numerous studies based on metal accumulation in various fish species. Fish may also be used for heavy metal monitoring programs of marine environments due to their easy sampling, sample preparation and chemical analysis. Concentrations of lead, cadmium, nickel, copper, manganese, zinc, iron, chromium, total mercury and total arsenic were determined in edible part of two commercially valuable fish Greek aquaculture species European sea bass (Dicentrarchus labrax) and gilthead sea bream (Sparus aurata) purchased from Bulgarian market during 2011. The concentration of metals was measured by atomic absorption spectrophotometry (AAS). The concentration of the heavy metals in examined fish species ranged as follow: $\mathrm{Pb}$ 0.008 - 0.013; Cd 0.0017 - 0.022; Ni $0.007-0.012$; Cu 0.054 - 0.115; Mn 0.043 - 0.09; Zn 0.14 - 0.15; Fe 0.17 - 0.19; Cr $0.05-0.07$; $\mathrm{Hg} 0.11-0.13$; As $1.6-1.8 \mathrm{mg} \mathrm{kg}^{-1}$ wet weight, respectively.

The concentration of the heavy metals obtained from this study is compared with the results of a Black Sea bluefish (Pomatomus saltatrix) caught during the same year. The concentration of metals was significantly affected by the sampling site and fish species. Difference in the heavy metal concentration between European sea bass, gilthead sea bream is observed for $\mathrm{Cu}, \mathrm{Mn}, \mathrm{Zn}$ and Fe. Although, the heavy metals in the edible parts of the investigated fish were in the permissible safety levels for human uses.
\end{abstract}

Keywords: Black Sea, fish, toxic elements.

\section{Introduction}

Anthropogenic activities introduce large amount of pollutants into the marine environment leading to significant and permanent disturbances of these pollutants in marine biological systems $[1,2]$. This is especially valid for costal zones, as these are considered as the main sinks of almost all pollutants introduced by humans. Metals in marine environments are ecotoxicologically significant since they are highly persistent and toxic even in traces. Contaminants, such as heavy metals, occur naturally in the environment. It is of a great importance to be able to distinguish anthropogenic contamination from background or natural levels in order to accurately evaluate the degree of contamination in a particular area [2].

Today the use of marine organism as bioindicators for heavy metals pollution in trace amounts is very common. Algae, molluscs and fishes are among the organisms most used for this purpose [2]. Fishes are good indicator for trace metal accumulation since the concentration of these metals is thousand times higher than the corresponding concentration in marine waters [2].

Monitoring of environmental quality uses biological species for evaluation of the biologically available levels of contaminants in the ecosystem and their effects on living organisms [2]. Thus, the use of biomonitors eliminates the need for complex studies on the chemical speciation of aquatic contaminants [1].

The Black Sea is considered as one of the most polluted seas in the world since it is closed sea and with anoxic waters (below $180 \mathrm{~m}$ ). Moreover, it receives freshwater inputs from some of the largest rivers in Europe (the Danube, the Dniester, and the Dnieper) which also contribute to its high degree of eutrophication and persistent pollutants [3, 4].

Aegean Sea is one of the main parts of the eastern Mediterranean [1]. In the north, it is 
connected to the Marmara Sea and Black Sea by the Dardanelles and Bosporus [5].

The objective of this work is to evaluate the concentration of some toxic elements (As, $\mathrm{Hg}, \mathrm{Pb}$, $\mathrm{Cd}$ and $\mathrm{Ni}$ ) and essential elements $(\mathrm{Cu}, \mathrm{Mn}, \mathrm{Zn}, \mathrm{Fe}$ and $\mathrm{Cr}$ ) in edible part of three pelagic fish species (European sea bass, gilthead sea bream and Black Sea bluefish) purchased from local Bulgarian market and to provide information on the marine environmental quality using fish samples as bioindicators of the degree of pollution.

\section{Experimental}

\subsection{Sampling}

The fish samples were purchased from the local market. The two commercially valuable fish Greek aquaculture species European sea bass (Dicentrarchus labrax) and gilthead sea bream (Sparus aurata) originates from Aegean Sea and are considered as fine foods. The Black Sea bluefish (Pomatomus saltatrix) was caught from the region of Varna, Bulgaria. The fish species were sampled during November 2011.

Table 1. Biometric data (mean \pm SE) of the analysed fish (Legend: AS-Aegean Sea; BS-Black Sea)

\begin{tabular}{|c|c|c|c|c|}
\hline Sample & Region & $\mathbf{N}$ & $\begin{array}{c}\text { Weight } \\
(\mathbf{g}) \pm \boldsymbol{S D}\end{array}$ & $\begin{array}{c}\text { Length } \\
(\mathbf{c m}) \pm \boldsymbol{S D}\end{array}$ \\
\hline $\begin{array}{c}\text { European } \\
\text { sea bass } \\
(\text { D.labrax })\end{array}$ & AS & 4 & $831.1 \pm 62.2$ & $43.3 \pm 7.6$ \\
\hline $\begin{array}{c}\text { Gilthead } \\
\text { sea bream } \\
(\text { S.aurata })\end{array}$ & AS & 6 & $538.3 \pm 40.6$ & $43.3 \pm 1.9$ \\
\hline $\begin{array}{c}\text { Black Sea } \\
\text { bluefish } \\
(\text { P.saltatri })\end{array}$ & BS & 3 & $209.6 \pm 53.5$ & $20.4 \pm 8.6$ \\
\hline
\end{tabular}

\subsection{Reagents and standard solutions}

All solutions were prepared with analytical reagent grade chemicals and ultra-pure water (18 $\mathrm{M} \Omega \mathrm{cm}$ ) generated by purifying distilled water with the Milli-QTM PLUS system. $\mathrm{HNO}_{3}$ was of suprapur quality was purchased from Fluka ${ }^{\circledR}$, Germany. All the plastic and glassware were cleaned by soaking in $2 \mathrm{M} \mathrm{HNO}_{3}$ for $48 \mathrm{~h}$, and rinsed five times with distilled water, and then five times with deionised water prior to use. The stock standard solutions of $\mathrm{Cd}$, As, $\mathrm{Ni}$ and $\mathrm{Pb}\left(1000 \mu \mathrm{g} \mathrm{mL}^{-1}\right)$ were Titrisol, Merck in $2 \% \mathrm{v} / \mathrm{v} \mathrm{HNO}_{3}$ and were used to prepare calibration standards.

\subsection{Sample digestion}

Fish samples are thoroughly washed with MQ water. The fish specimens were dissected and samples of fish fillets quickly removed and washed again with MQ water. To assess the total metal contents, microwave assisted acid digestion procedure was carried out. Microwave digestion system "Multiwave", "Anton Paar" delivering a maximum power and temperature of $1000 \mathrm{~W}$ and $300{ }^{\circ} \mathrm{C}$, respectively, and internal temperature control, was used to assist the acid digestion process (Table 2).

Table 2. Microwave digestion system general parameters

\begin{tabular}{|l|l|}
\hline \multicolumn{2}{|c|}{$\begin{array}{c}\text { Microwave digestion system "Multiwave", } \\
\text { "Anton Paar" Acid mixture }\end{array}$} \\
\hline $\mathrm{HNO}_{3}$ & $6.5 \mathrm{~mL}$ \\
\hline Temperature (max) & $300^{\circ} \mathrm{C}$ \\
\hline Pressure (max) & $75 \mathrm{bar}$ \\
\hline Quartz vessels & $\mathrm{HQ} 50$ \\
\hline Sample amount & $1 \mathrm{~g}$ \\
\hline Final volume & $10 \mathrm{~mL}$ \\
\hline
\end{tabular}

Reactors were subjected to microwave energy at $800 \mathrm{~W}$ in five stages program described below (Table 3).

Table 3: Microwave digestion system operational parameters

\begin{tabular}{|c|c|c|c|}
\hline Step & $\begin{array}{c}\text { Initial } \\
\text { power } \\
(\mathbf{W})\end{array}$ & $\begin{array}{c}\text { Time } \\
(\mathbf{m i n})\end{array}$ & $\begin{array}{c}\text { Final } \\
\text { power } \\
(\mathbf{W})\end{array}$ \\
\hline 1 & 100 & 5 & 600 \\
\hline 2 & 600 & 5 & 600 \\
\hline 3 & 600 & 5 & 800 \\
\hline 4 & 800 & 15 & 800 \\
\hline 5 & 0 & 15 & 0 \\
\hline
\end{tabular}

Determination of As was performed using Electrothermal AAS carried out on a Perkin Elmer (Norwalk, CT, USA) Zeeman 3030 spectrometer with an HGA-600 atomizer. Pyrolytic graphite- 
coated graphite tubes with integrated platforms were used as atomizers (Table 4).

Determination of $\mathrm{Fe}, \mathrm{Mn}, \mathrm{Cu}$ and $\mathrm{Zn}$ was done by Flame atomic absorption spectrometry. Measurements were carried out on a Perkin Elmer (Norwalk, CT, USA) Zeeman 1100 B spectrometer with air/acetylene flame. The instrumental parameters were optimized in order to obtain maximum signal-to-noise ratio.

Determination of $\mathrm{Hg}$ was done by Milestone Direct Mercury Analyzer DMA-80 (Fig. 1).

A DORM-2 (NRCC Canada) certified dogfish tissue was used as the calibration verification standard. Recoveries showed good agreement between the certified and the analytical values, the recovery of elements being partially complete for most of them. For DORM-2 this recovery was in the range of $93(\mathrm{Zn})$ up to $109 \%(\mathrm{Cd})$

\subsection{Statistical analysis}

The whole data were subjected to a statistical analysis. Student's-test was employed to estimate the significance of values.

\section{Results and Discussions}

Two groups of elements were established for all the data obtained. One group contained elements known to be essential to life and to be present in all animal tissues, e.g. $\mathrm{Mn}, \mathrm{Fe}, \mathrm{Cu}, \mathrm{Cr}$ and $\mathrm{Zn}$ (Fig. 2).
The second group of elements are non-essential, namely $\mathrm{Hg}, \mathrm{Ni}, \mathrm{Pb}$, As and $\mathrm{Cd}$, reflect an exogenous influence that may be related to environmental pollution [8]. These elements are referred to as toxic elements and their concentrations for the studied samples are displayed in Fig. 4.

The accumulation patterns tend to vary among species based on their behavior and feeding habits [9] which are in accordance with the results in this study.

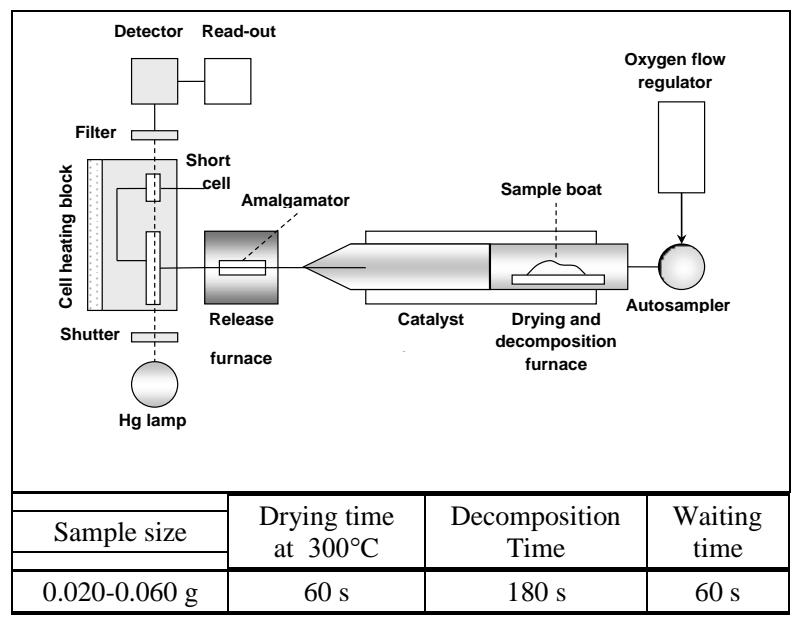

Figure 1. Steps and conditions for total mercury determination in fish by DMA- 80

Table 4: Instrumental parameters for HGA 600

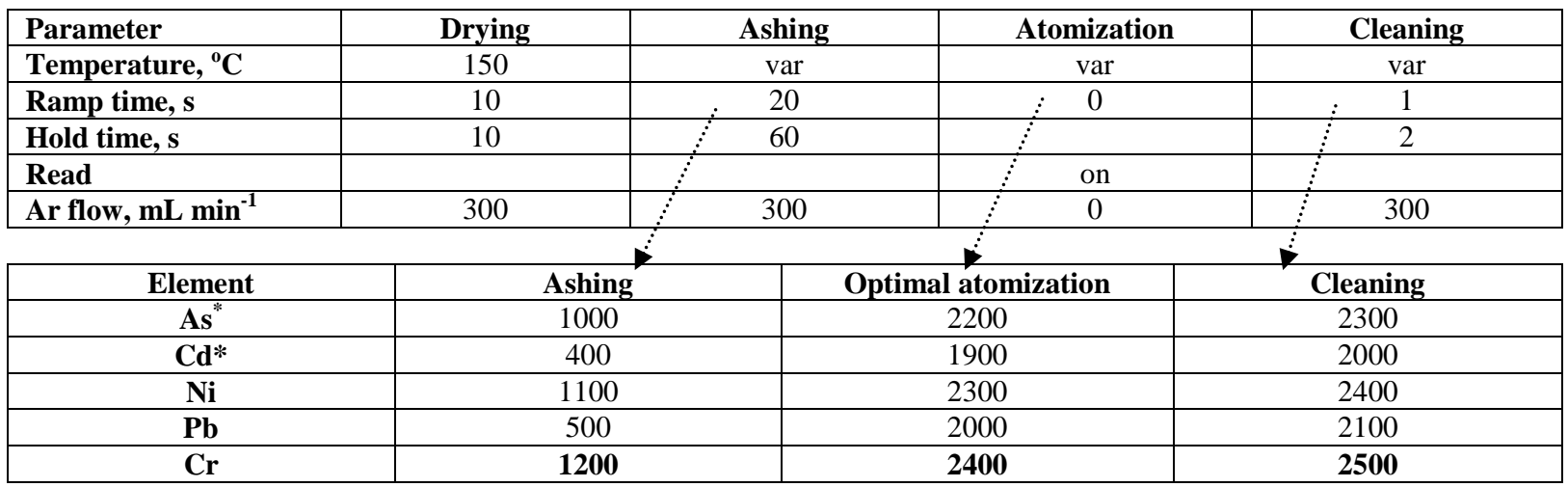

- modifier $\mathrm{Pd}$ as $\left(\mathrm{NH}_{4}\right)_{2} \mathrm{PdCl}_{4}$ 


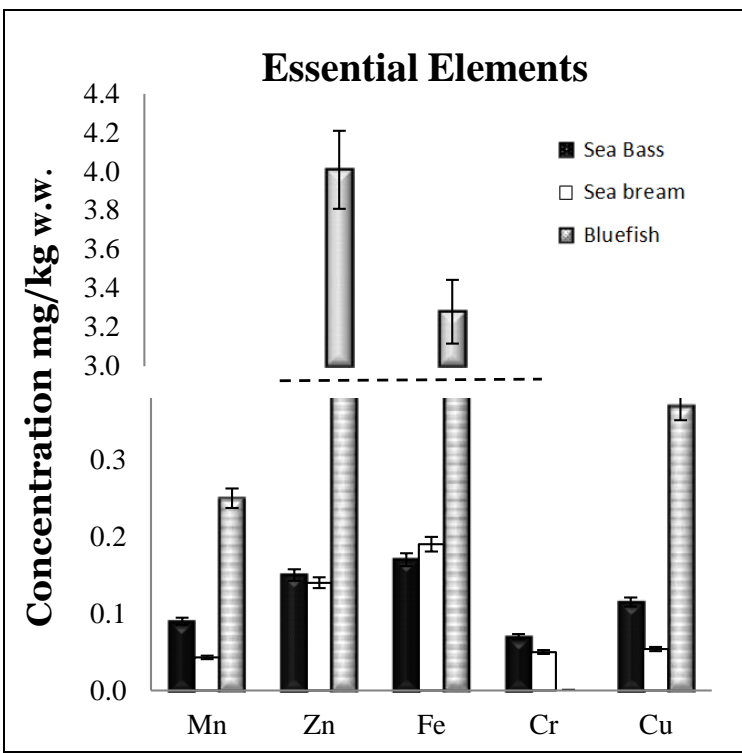

Figure 2. The mean metal concentration of the analyzed essential elements $(\mathrm{mg} / \mathrm{kg} \mathrm{w} . \mathrm{w} \pm \mathrm{SD})$ in the tissues of sea bass, sea bream and bluefish

In D. labrax mean As (1.8 mg/kg w.w.) and $\mathrm{Hg}$ $(0.13 \mathrm{mg} / \mathrm{kg} \quad$ w.w. $)$ concentrations appear considerably higher in the muscle, followed by the concentration of $S$. Aurata $(1.6 \mathrm{mg} / \mathrm{kg} \mathrm{w} . \mathrm{w}$ and 0.11 $\mathrm{mg} / \mathrm{kg} \mathrm{w.w}$, respectively)

$\mathrm{Fe}, \mathrm{Zn}, \mathrm{Cu}$ and $\mathrm{Mg}$ are essential elements and they play a virtual role in biological systems. The non-essential metals as $\mathrm{Cr}, \mathrm{Pb}, \mathrm{Ni}$ and $\mathrm{Cd}$ are toxic even at trace amounts [1]. The essential metals can also produce toxic effects when the metal intake is excessively elevated [6]. According to European Union only three metals $(\mathrm{Pb}, \mathrm{Hg}$ and $\mathrm{Cd})$ have been included in the regulation for hazardous elements [7]. Additionally, USFDA expands that list with another three elements (As, $\mathrm{Ni}$ and $\mathrm{Cr}$ ) [8].

The concentration of the essential elements in this study is higher for the marine fish species. The predominant element is $\mathrm{Zn}$ followed by $\mathrm{Fe}, \mathrm{Cu}$ and $\mathrm{Mn}$. On the other hand the concentration of $\mathrm{Cr}$ for both fish species caught from Aegean Sea is higher than that of Black Sea bluefish.

Iron concentrations in fish species ranged from $0.17 \mathrm{mg} / \mathrm{kg}$ metal w.w in the muscle of sea bass to $3.28 \mathrm{mg} / \mathrm{kg}$ metal w.w in the muscle of bluefish. These values are lower or within those measured in some edible fish by other authors. Carvalho et al. [9]

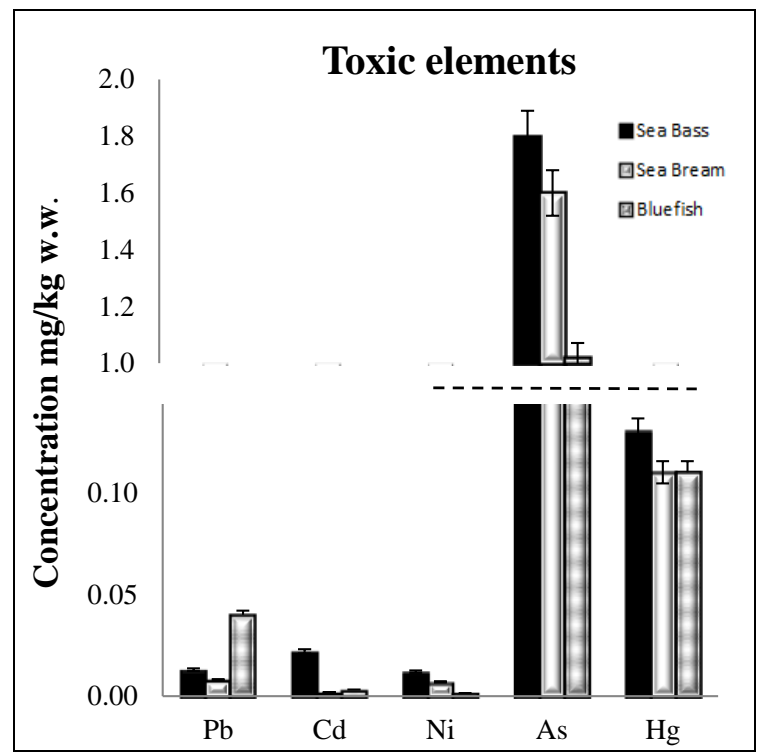

Figure 3. The mean metal concentration of the analyzed toxic elements $(\mathrm{mg} / \mathrm{kg} \mathrm{w} . \mathrm{w} \pm \mathrm{SD})$ in the tissues of sea bass, sea bream and bluefish

obtained Fe values in fish species ranged from 6.4 $\mu \mathrm{g} / \mathrm{g}$ (forkbeard) to $16 \mu \mathrm{g} / \mathrm{g}$ (axillary sea bream), but the highest concentration was observed for octopus $(109 \mu \mathrm{g} /)$. Concentration in the literature were reported between 59.6 and $73.4 \mathrm{mg} / \mathrm{kg}$ for muscles of fish from Mediterranean Sea [10], 30-160 mg/kg for muscles of fish from the Black Sea coasts [11] and $9.52-32.40 \mathrm{mg} / \mathrm{kg}$ dry weight in fish samples of the middle Black Sea (Turkey) [6]. The iron content in fish samples depends on species, individuals, and sampling period. High concentration of iron could depend on the individual diet of the fish species as well as its habitants. Our iron concentrations were generally in agreement with the literature data.

The manganese values in our study were between 0.043 and $0.25 \mathrm{mg} / \mathrm{kg} \mathrm{w.w.} \mathrm{Manganese} \mathrm{has}$ been reported in the range of $1.30-3.10 \mathrm{mg} / \mathrm{kg}$ for muscles of fish from Iskenderun Bay [12]. In an another study of Iskenderun Bay [1], manganese was detected in almost all the samples and the concentration ranged from 1.04 to $8.77 \mu \mathrm{g} / \mathrm{g}$ metal w.w., with the highest concentration rate detected in T. lucerna tissues. Total daily intake varies from 2.5 to $7 \mathrm{mg}$ for humans [13].

Copper concentrations varied from $0.054 \mathrm{mg} / \mathrm{kg}$ w.w in sea bream to $0.37 \mathrm{mg} / \mathrm{kg}$ w.w in Black Sea bluefish. The concentrations in muscles of the 
samples were below the toxic limit of $30 \mathrm{mg} / \mathrm{kg}$ [14]. As copper is an essential part of several enzymes and necessary for the synthesis of haemoglobin, most marine organisms have evolved mechanisms to regulate concentrations of this metal in their tissues in the presence of variable concentrations in the ambient water, sediments, and food [1].

$\mathrm{Zn}$ is very useful in biological system. It plays role in normal immune function, sexual functions and neurosensory function. Zinc is toxic above the limit of 50 w.w. in muscle tissues of different fish species [15]. It is believed to have a protective effect against the toxicities of $\mathrm{Cd}$ and $\mathrm{Pb}$. In this study the zinc content in the samples ranged from $0.14 \mathrm{mg} / \mathrm{kg}$ w.w. in Aegean Sea bream up to $4.01 \mathrm{mg} / \mathrm{kg} \mathrm{w.w.} \mathrm{in}$ Black Sea bluefish and it is within the values set by Bulgarian Food Codex (the maximum zinc level permitted for fishes is $50 \mathrm{mg} / \mathrm{kg}$ ) [10].The range of that concentration in the literature is from 20.8 to $47.6 \mu \mathrm{g} / \mathrm{g}$ w.w., with a high level in skin of $T$. Lucerna (47.6 $\mu \mathrm{g} / \mathrm{g}$ w.w.) and L. budegassa (43.8 $\mu \mathrm{g} / \mathrm{g}$ w.w.) samples [1] and 4.49-11.6 mg/kg for muscle tissues of various fish species from Marmara, Aegean and Mediterranean Sea [17].

Chromium is microelement that paly role in glucose metabolism. It was detected in all the analyzed samples, with the highest concentration $(0.07 \mathrm{mg} / \mathrm{kg}$ w.w. $)$ in muscle of $D$. labrax but the values were within the limits of $0.3 \mathrm{mg} / \mathrm{kg}$ set by Bulgarian Food Codex [16].

$\mathrm{Cd}$ is a widely distributed contaminant introduced in the environment through the urban and industrial activities and transported in the air. The upper limit allowed for fish muscle is $0.05 \mathrm{mg} / \mathrm{kg}$ w.w. according to EU legislation and FAO/WHO [7, 14]. The concentrations for all the sample muscles analysed (0.0017 - $0.022 \mathrm{mg} / \mathrm{kg}$ w.w.) were below the value set by various institution. In our previous study on heavy metal pollution in muscle tissue of bluefish, the cadmium levels were below $0.07 \mathrm{mg} / \mathrm{kg}$ fresh weight [18]. Cadmium concentration in literature has been reported as follow: 0.02-0.37 $\mathrm{mg} / \mathrm{kg}$ for edible part of fishes caught from Marmara, Aegean and Mediterranean seas in Turkey [17] and $0.002-0.02 \mathrm{mg} \mathrm{Cd} \mathrm{kg}^{-1}$ fresh weight for species from Adriatic Sea [19].

Mean nickel concentrations ranged from 0.007 $\mathrm{mk} / \mathrm{kg} \mathrm{w.w.} \mathrm{in} \mathrm{sea} \mathrm{bream} \mathrm{to} 0.015 \mathrm{mg} / \mathrm{kg}$ w.w. bluefish. These results are similar to those reported in the literature: 0.54 to $1.84 \mu \mathrm{g} / \mathrm{g}$ w.w. in the three fish species from Iskenderun Bay, Black Sea, Turkey [11], 0.06-0.39 mg/kg in muscles of fish Ria de Averio, Portugal [20]. However, Ni levels in the present study were lower than those reported in fishes from the Atlantic [21] and from the Mediterranean seas [22].

Arsenic concentrations varied from $1.02 \mathrm{mg} / \mathrm{kg}$ for bluefish to $1.8 \mathrm{mg} / \mathrm{kg}$ for sea bass; however, these values are well below the maximum level permitted for fishes according to Bulgarian standards (5.0 mg/kg fresh weight) [16]. Tuzen [6] had measured an arsenic concentration in different fish species from Black Sea as follows: $0.15 \pm 0.01$ $\mu \mathrm{g} / \mathrm{g}$ for Psetta maxima; $0.27 \pm 0.02 \mu \mathrm{g} / \mathrm{g}$ for Pomatomus saltator, $0.23 \pm 0.01 \mu \mathrm{g} / \mathrm{g}$ for Mugil cephalus, $0.14 \pm 0.01 \mu \mathrm{g} / \mathrm{g}$ for Sarda sarda, $0.18 \pm 0.02 \mu \mathrm{g} / \mathrm{g}$ for Trachurus trachurus and $0.17 \pm 0.01 \mu \mathrm{g} / \mathrm{g}$ for Sprattus sprattus. The concentration of arsenic reported in fish species from Adriatic Sea ranged of 0.56 to $10.03 \mathrm{mg} / \mathrm{kg}$ fresh weight [19] and up to $1.74 \mu \mathrm{g} / \mathrm{g}$ w.w. in the muscle of $S$. Lascaris in Turkish part of the Black Sea [1].

The lead contents were $0.008 \mathrm{mg} / \mathrm{kg} \mathrm{w.w}$. for Aegean sea bream to $0.04 \mathrm{mg} / \mathrm{kg}$ w.w. for Black Sea bluefish. Lead in the literature have been reported in the range of $0.33-0.93 \mathrm{mg} / \mathrm{kg}$ in muscles of fish from Black and Aegean seas [23], 0.01-0.15 mg/kg in muscles of fish from Ria de Averio, Portugal [20]. The Joint FAO/WHO Expert Committee on Food Additives established a Provisional Tolerable Weekly Intake (PTWI) for lead of $0.025 \mathrm{mg} / \mathrm{kg}$ body weight/week [7] which was equivalent to 1.725 $\mathrm{mg} /$ week for a $70 \mathrm{~kg}$ adult.

Mercury is a known human toxicant and the primary sources of mercury contamination in man are through eating fish [24].The lowest and highest mercury levels in fish species were found as 0.11 $\mathrm{mg} / \mathrm{kg}$ in Black Sea bluefish and Aegean Sea bream and $0.13 \mathrm{mg} / \mathrm{kg}$ in Aegean Sea bass. The maximum $\mathrm{Hg}$ level permitted for fishes is $0.5 \mathrm{mg} / \mathrm{kg}$ according to Bulgarian Food Codex [16]. The PTWI is $5 \mathrm{mg}$ total mercury $\mathrm{kg}^{-1}$ body weight (bw) and $3.3 \mathrm{mg}$ methylmercury $\mathrm{kg}^{-1}$ bw was reduced to $1.6 \mathrm{mg}$ methylmercury $\mathrm{kg}^{-1}$ bw [25] and could be exceeded depending on the species and quantity consumed. Mercury levels in analyzed fish samples were found 
to be lower than legal limits. In the literature mercury levels in fish samples have been reported in the range of $0.01-0.50 \mu \mathrm{g} / \mathrm{g}$ in marine fishes in Malaysia [26] and 25-84 $\mu \mathrm{g} / \mathrm{kg}$ for fishes from Black Sea [27].

\section{Conclusions}

This study was carried out to provide information on heavy metal concentrations in edible part of different fish species from Aegean Sea and Black Sea purchased from the local markets in Bulgaria. All results showed that the highest levels of essential metals were determined in the species from Black Sea while the toxic elements were higher in the fish species from Aegean Sea. However, the results for essential and toxic metals are below the limit values for fish and it may be concluded that consumption of these species from both region is not a problem for human health.

Although the concentrations of the analysed toxic elements for fish samples from Aegean Sea and Black Sea are below the official limits set for fish, a potential danger may emerge in the future, depending on the domesticwaste waters and industrial activities in the region.

Additionally the fishes cover this study represent good biomonitors of metals present in the surrounding environment.

\section{References}

* e-mail address: peytcheva@ hotmail.com

[1]. A.B. Yılmaz, M.Kemal Sangun, D. Yaglioglu and C. Turan, Food Chemistry 123, 410-415 (2010)

[2]. I. Akcali and F. Kucuksezgi, Marine Pollution Bulletin 62, 637-45 (2011)

[3]. T. Stoichev, L.Makedonski, T. Trifonova, M. Stancheva and F. Ribarova, Chemistry and Ecology 23, 191-200 (2007)

[4]. M. Stancheva, L. Makedonski and K. Peycheva, Bulgarian Chemical Communications 46, 195 - 203 (2014)

[5]. G.W. Bryan and W.J. Langston, Environmental Pollution 76, 89-131 (1992)

[6]. M. Tuzen, Food Chemistry 80, 119-123 (2003).

[7]. *** EU Commission Regulation as regards heavy metals. Directive 2001/22/EC, No.
466/2001 EEC as amended by regulation 221/2002/EC

[8]. *** USFDA (1993). Food and drug administration. Guidance document for arsenic in shellfish. DHHS/PHS/FDA/CFSAN/Office of Seafood, Washington, DC

[9]. M. L Carvalho, S.Santiago and M. L. Nunes, Analytical and Bioanalytical Chemistry 382, 426-432 (2005)

[10]. M. Kalay, O. Ay and M. Canli, Bulletin of Environmental Contamination and Toxicology 3, 5, 673-681 (1999)

[11]. S. Topcuoğlu, C. Kırbaşoğlu, and N. Gungor, Environment International. 27, 521-526 (2002).

[12]. A.Turkmen, M.Turkmen, Y.Tepe and I. Akyurt, Food Chemistry 91, 167-172 (2005)

[13]. *** NAS-NRC. National Academy of Sciences-National Research Council Drinking Water and Health (Vol. 1). Washington, DC: National Academic Press. p. 1939

[14]. *** FAO (2008) <http:/www.fao.org/es/ESS /faostat/foodsecurity/index_en.htm>

[15]. E. J Calabrese, A.Canada and C. Sacco, Annual Review of Public Health 6, 131-146 (1985).

[16]. *** Anonymous, Darjaven Vestnik, 08 October 2004, Issues 88 (2004)

[17]. M. Turkmen, A. Turkmen, Y. Tepe, A. Ateş, and K. Gokkuş, Food Chemistry 108, 2, 794800 (2008)

[18]. M. Stancheva, K. Peycheva and L. Makedonski, Ovidius University Annals of Chemistry 21, 41-48 (2010)

[19]. D. Jureša and M. Blanuša, Food Additives and Contaminants 20, 241-246 (2003)

[20]. B. Perez Cid, C. Boia, L. Pombo and E. Rebelo, Food Chemistry 75, 93 (2001)

[21]. J. Usero, C. Izquierdo, J. Morillo, and I. Graciac, Environment International 29, 949$956(2003)$

[22]. M. M. Storelli, G. Barone, A. Storelli and G.O. Marcotrigiano, Bulletin of Environmental Contamination and Toxicology 77, 43-50 (2006)

[23]. O.D. Uluozlu, M. Tuzen, D. Mendil and M. Soylak, Food Chemistry 104, 835 (2007)

[24]. K.Peycheva, L. Makedonski, A. Merdzhanova, and M.Stancheva, Ovidius University Annals of Chemistry 25, 53-58 (2014) 
[25]. *** JECFA, Summary of Evaluations Performed by the Joint FAO/WHO Expert Committee on Food Additives: Mercury. Available: http://www.inchem.org/documents/ jecfa/jeceval/jec_1285.htm. Accessed: 10 March 2007

[26]. P. Hajeb, S. Jinap, A. Ismail, A. B. Fatimah, B. Jamilah and M. A. Rahim, Food Control 20, 79-84 (2009)
[27]. M. Tuzen Food and Chemical Toxicology 47, 1785-1790 (2009)

Received: 20 April 2015 Received in revised form: 19 May 2015 Accepted: 22 May 2015 